\title{
From Peril to Promise: Repositioning Higher Education for the Reconstruction of Africa's Future
}

\author{
Ibrahim Oanda and Ebrima Sall
}

\begin{abstract}
What efforts and policy commitments need to be made, to ensure that higher education in Africa is central to realizing Africa's development imperatives? Both in Africa and among the development partner community, academics and policy makers recognize the importance of higher education for Africa's development. Public and private higher education institutions are expanding, boosting enrollments. In most countries, new buffer bodies have been created to provide governance oversight, guarantee greater institutional autonomy from undue political control, and strengthen the institutions, to allow them engage in national and continental development issues. Greater policy commitments from the African Union Commission (AUC) have rejuvenated regional higher education bodies working to set quality assurance frameworks, and reorganized commissions for science and technology that are mobilizing funding for research and innovation for higher education institutions. Are these developments leveraging higher education institutions to play new important roles in crafting Africa's future? What will it take for Africa's higher education to be pivotal in reconstructing Africa's future?
\end{abstract}

Quels sont les efforts et les engagements politiques qui doivent être mis en œuvre pour s'assurer que l'enseignement supérieur joue un rôle central dans la réalisation des impératifs de développement en Afrique

ABOUt THE AUthoRs: IBRAHIM OANDA, is senior program officer and head of the Training, Grants and Fellowship program at CODESRIA. E-mail: ibrahimoanda@ gmail.com.

EBRIMA SALL is the executive secretary of CODESRIA. E-mail: ebrima.sall2or3@ gmail.com. 
? Que ce soit en Afrique ou parmi la communauté des partenaires du développement, les universitaires et les décideurs politiques reconnaissent l'importance de l'enseignement supérieur pour le développement du continent. Les établissements d'enseignement supérieur publiques et privés se développent, entraînant une augmentation des inscriptions. Dans la plupart des pays, de nouveaux organismes tampons ont été créés afin d'assurer une surveillance de la gouvernance, de garantir une plus grande autonomie institutionnelle vis-à-vis d'un contrôle politique injustifié, et de renforcer les institutions pour leur permettre de s'engager pleinement dans des enjeux de développement à l'échelle nationale et continentale.

Un plus grand engagement politiques de la part de la Commission de l'Union Africaine (CUA) a permis de revivifier l'activité d'organismes régionaux d'enseignement supérieur chargés d'instaurer des cadres d'assurance qualité, et de mener à la réorganisation des commissions pour la science et la technologie qui mobilisent les fonds pour la recherche et l'innovation destinés aux établissements d'enseignement supérieur. Ces développements ont-ils poussé les institutions d'enseignement supérieur à jouer d'importants nouveaux rôles dans l'élaboration de l'avenir africain ? Que faudra-t-il faire pour que l'enseignement supérieur en Afrique devienne central dans la reconstruction de l'avenir de l'Afrique ?

\section{Introduction}

What efforts and policy commitments need to be made, to ensure that higher education in Africa is central to realizing Africa's development imperatives? Academics and policy makers, both in Africa and among the development partner community, recognize the importance of higher education for Africa's development. The African Union's longterm development strategy, Agenda 2063, recognizes the role of higher education in achieving the objectives set in the strategy. This include, among others, creating a prosperous Africa based on inclusive growth and sustainable development, one united in diversity and conscious of its history. A higher education focused on a balanced teaching of the hard sciences to develop new technology driven businesses as well as the social sciences and humanities would drive these continental ambitions. At the level of individual countries public and private higher education institutions are expanding, boosting enrolments. In most countries, new buffer bodies have been created to provide governance oversight, guarantee greater institutional autonomy from undue political control, and strengthen the institutions, to allow them engage in national and continental development issues. Greater policy commit- ments from the African Union Commission (AUC) have rejuvenated regional higher education bodies working to set quality assurance frameworks, and reorganized commissions for science and technology that are mobilizing funding for research and innovation for higher education institutions. Are these developments leveraging higher education institutions to play new important roles in crafting Africa's future, or they are walking backward along similar paths that they have walked before? What will it take for Africa's higher education to be pivotal in reconstructing Africa's future?

From Peril to Promise or from Promise to Peril? The Context

After two decades of reforms that promised so much for higher education systems in developing countries, but achieved little, the World Bank issued another commissioned report in 2000, "Higher Education in Developing Countries: Peril and Promise" (2000). The report acknowledged the perilous state of higher education in most developing countries, with a special focus on issues such as funding and resources, governance, and curriculum. These challenges persisted, the report pointed out, even at a time when it was becoming increasingly evident that developing countries needed more and better higher education to benefit from the global knowledge economy. "From Peril to Promise" was issued at the same time as another report, "Can Africa Claim the 2Ist Century?" (World Bank 2000), which devoted chapters to "investing in people", but with scant mention of the direction Africa's higher education needed to take if it had to claim a role for Africa's development in the 2Ist century. To some degree, the two documents are at odds with each other; one showing higher education as an area of much promise, which developing countries need to invest in; and the otherthough mulling what Africa should do to claim the 2Ist century-giving insufficient attention to an area acknowledged and promoted as crucial for developing countries, in order to benefit from the global knowledge economy.

"From Peril to Promise" did not clearly acknowledge the fact that the vulnerable state of higher education in most developing countries by and large was the result of World Bank policies that had been designed and implemented with the same logic as the other report of 2000 . Higher education institutions in Africa, or at least the university sector, had not always been vulnerable. Established during the late colonial period to promote the narrow interests of the colonial project, most of them performed well, once adopted as national projects in the I970s. The number of higher education institutions and students in Africa surged in response to the demand for skilled personnel to run the new nations. 
While there were only I3 universities in sub-Saharan Africa in I960, by 2002 there were about 300 . The institutions performed well before the imposition of neoliberal policies. Recalling the glorious past of Africa's higher education, Aina (20I5), refers to an era when vibrant intellectual communities such as the "Ibadan School of History," "the"Dar es Salaam Social Sciences School," the "Legon School of Philosophy," the "Dakar School of Philosophy," among others, attracted scholars and students from all over the world; were funded by African governments and private foundations; contributed to knowledge, development, and policies in Africa; generated research; were platforms for major debates; and produced scholars and publications that were internationally influential. It is not that higher education in Africa had always been wanting, or that suffered from limitations such as lack of internationalization and relevant knowledge production. Back then, institutions thrived and the quality of their engagement was never in doubt.

Signs of stress emerged in the early I980s. The few existing flagship universities were not able to adequately expand and address equity, and their operations became inefficient. While they were largely used as a tool for political patronage and manipulation since their establishment as national institutions, the public largesse that sustained them began to wane due to a downturn in the global economy. This coincided with a period of increased pressure to expand, partly due to campaigns for universal primary and secondary education carried out by African governments as a dividend for political independence.

Much of this was achieved through use of carrot and stick policies and, sometimes, personal university management initiatives, but at a great cost. All over Africa, a combination of policies was pursued, including a tacit encouragement for the establishment of private universities, reduction of public subsidies to public universities and the introduction of user fees. As a result of resistance to these reforms, public universities shut down for long periods, thereby giving space to private universities to establish themselves as alternatives.

The devastating effects wrought on higher education in particular, and on the social sectors of developing countries more generally, once Structural Adjustment Programs (SAPS) were adopted in the I980s, have been variously discussed (Federici, Caffentzis, and Alidou 2000; Samoff and Bidemi 2004). In the case of sub-Saharan Africa, adjustment policy packages were persuasively argued for in the World Bank policy document "Education in Sub-Saharan Africa; Policies for Adjustment, Revitalization, and Expansion" (I988). Its prescriptions were not entirely altruistic, though correct in diagnosing the problems then faced by the higher education sector-mostly accruing, not from any inter- nal incapacity of the institutions, but from the limitation of resources caused by the overall adjustments in the economy proposed by the Bank. In higher education, the adjustment policies forced the emergence of private higher education markets, camouflaged as a reform. This came to herald the Bank's neoliberal agenda in the provision and governance of higher education, which entailed privatization through the establishment of privately owned and financed institutions of higher education; introducing fees in public establishments under state-set standards; promoting an educational credit market; and imposing a special tax on earnings of tertiary-level graduates during a transition to an effective system of graduated income tax. These measures were meant to address the problem of low quality and inefficiency in the higher education system (World Bank I988: 79-80).

The subsequent framing and recommendation from the Bank on the direction higher education development in Africa was to follow echoed previous prescriptions. In the words of the Bank's 2000 Report, and the subsequent "Constructing Knowledge Societies: New Challenges for Tertiary Education" (2002), higher education would be important only if it focused on certain curriculum offerings and skills considered critical to creating knowledge economies, or enabling countries to benefit from such economies as consumers. Henceforth, the World Bank policy reports influenced various developments in African higher education in the 2000-20I0 decade. Central to the developments was the adoption by higher education policy makers in Africa of the assertion that education in science, technology, engineering, and mathematics (STEM) is correlated with better economic performance; that higher education is critical in improving primary and secondary education; and that the adoption of distance learning mechanisms to expand the reach and connectivity of tertiary education institutions is critical to expanding access (Bloom et al. 20I4). The other assertion was that in evolving knowledge economies, growth would be based substantially on the development of human capital rather than means of production, thereby putting pressure for the expansion of higher education systems to increase enrollments.

African countries and institutions have acquiesced to these policy prescriptions, focusing on quantitative expansion of institutions, student numbers, and programs, without commensurate increase in public investment in higher education. This has sparked quality concerns. The number of private higher education institutions has increased to about double the number of public institutions, but enrolled only 25 percent of students continent-wide (Bloom et al. 20I4).

The World Bank report of 2000 continues to receive great attention 
as a turning point, giving directions to efforts to revitalize higher education in Africa. When discussing the future of higher education on the continent, government policy makers and academics often proceed from the justification that "even the World Bank has now accepted that higher education is important for Africa," and then proceed to proffer policy measures along the lines suggested in the policy documents. Beyond acknowledging that higher education is important because the World Bank has said so, they rarely delve into reflecting on the kind of higher education that the continent requires. In accepting such policies so readily, policy makers assume that the World Bank departed fundamentally from its earlier policies, which aggravated the problems in higher education in the first place (see for example critics Utne-Brock 2003; Samoff and Bidemi 2004). But this has not been the case. As Robertson (2OII) asserts while commenting on the Bank's supposedly reformed "Education Strategy 2020," there has been no change of logic in the Bank's neoliberal policies. Rather, the Bank continues to reinvent and offer more of the same old policies, but repackaged in new formulations.

The most important revolution in higher education provision in Africa, however, did not come from the imposition of the World Bank policy prescriptions, most of which remain contested to date. Rather, it has been a result of three developments internal to Africa, confirming the fact that the most promising alternatives to developing higher education are likely to be generated internally. The first was an initiative taken by universities to generate their own resources through the admission of private sponsored students. The World Bank prescription on this was for countries to set up better regulatory environments for the establishment and growth of private universities. This did not happen, however, even with the establishment of regulatory bodies. Instead, public universities in countries like Uganda, Kenya, Nigeria, and Ghana continued to grow and the decisions to introduce private student schemes in the public institutions expanded access to higher education in a more meaningful way. The second development was the end of apartheid in South Africa in I994. Coupled with the Southern African Development Community (SADC) arrangement that allows preferential quotas for students from the region, this opened a huge higher education space in Africa for students that would otherwise be seeking higher education outside the continent. And the third has been the effect of these two developments in attracting African academic diaspora resources back to the continent.

Arguably, many of the developments underway in African higher education, including greater coordination at continental level and increased expansion at national level, stream from the logic of these World Bank policies and other external support. Not much policy attention is being given to exploring internal capacities for policy, reform, and direction of African higher education, including the often-postponed issue of how to decolonize the institutions to make them truly African. It was for example evident, among most presentations at the "Africa Higher Education Summit" held in Dakar, Senegal, from Io to I2 March 20I5 on the theme of "Revitalizing Higher Education for Africa's Future," that the change of perspective of the World Bank was a relief for policy makers and academics in Africa, allowing them to articulate policies and perhaps commit a little more resources to the sector without fear of censorship from donors. The contradiction is that, two decades earlier, similar support was given to the Bank's policy that discouraged investments in higher education. The flaws in these policy alterations are that African countries have, over time, failed to develop internal strategies to reform higher education and make it responsive to their development needs. Rather, policies have been responses to external developments, and once implemented they ended up alienating the higher education sector from the context whose problems they were supposed to solve. The national level reactions to the World Bank's positive assertion on the role of higher education have, for example, witnessed knee-jerk reactions informed by political populism and declarations to establish more universities as government control over them tightened. This has only meant setting up institutions that are not sufficiently funded to meet the development challenges that most countries are experiencing. The lack of internal political capacity to design a strategy for higher education reform and development continue to create space for policy imposition from outside.

What then is the state of African higher education today? What is its potential, and is the World Bank's policy a credible promise to deliver the sector from a perilous path to one of greater accomplishment? The remaining part of this chapter reviews developments on four challenges that need to be addressed internally: access, governance, quality, and knowledge production and curricular relevance.

\section{The Challenge of Broadening Access}

The 2000 World Bank report identified broadening access-especially to accommodate students from disadvantaged backgrounds and enable them to acquire specialized skills - as a crucial challenge for African countries (World Bank 2000). The subsequent report "Constructing Knowledge Societies: New Challenges for Tertiary Education” (World Bank 2002) reinforced this observation, pointing out as an unresolved 
issue the sustainable expansion of tertiary education coverage and the reduction of inequalities of access and outcomes, through increasing institutional diversification and the growth of non-university and private institutions. It is therefore important to analyze how higher education has expanded and who has benefited most, in terms of quality of institutions and programs.

Even with a lack of comprehensive data, there is evidence that higher education institutions and enrollments have grown in most of Africa in the post-I990 period. Available data indicate a sharp increase in enrollments over the last two decades, with increases averaging I70 percent, from 3.53 million students in I999 (2.25 million in subSaharan Africa and I.28 million in North Africa) to 9.54 million in 2012 (6.34 million in sub-Saharan Africa and 3.2 million in North Africa) (AfDB 20II, UNESCO 20I2). The number of public and private higher education institutions has also grown. Public institutions have expanded tremendously in terms of students and academic programs. Data from the International Association of Universities, the African Association of Universities (2013), and UNESCO (as background material for the African higher education summit in Dakar in June 20I5) show that the number of public universities in the continent rose from I09 institutions in 1990 to 659 in 20I0, while that of private universities rose from 234 to 969 within the same period. This means that the number of public and private universities in the continent, besides other postsecondary higher education institutions, stood at I 628 institutions. This number must have since gone up, with major expansions in countries such as Ghana, Ethiopia, and Kenya since 2010.

The downside of this expansion, however, has been that private higher education institutions that are the majority in terms of numbers have fewer students and fewer academic programs, specializing mostly in business-related subjects and social sciences. On the other hand, public universities have expanded largely, not through the establishment of new institutions, but through the transformation of middle-level vocational colleges into universities. The end result is that the expanded institutions offer a curriculum that is too general and instill too few of the practical skills that small businesses or selfemployment require: less than 5 percent of postsecondary education students are enrolling in technical and vocational programs in Africa (African Economic Outlook 20I5). In other words, the expansion of the institutions, especially of private universities, seems to accentuate what has been seen as a negative trend in university enrollments: Africa has the highest share of social science and humanities graduates of any region in the world, and the lowest share of engineers, with for example only 2 percent of enrollments in agriculture-although the African continent is basically rural (African Economic Outlook 20I5).

There is also a concern that despite this expansion, higher education gross participation rates in the continent do not seem to rise as fast, and opportunities within the continent have not markedly stemmed the outward mobility of students. The higher education gross enrollment ratios (GER) for Sub-Saharan Africa stood at 8 percent, whereas Arab states (including those outside of the African continent) enrolled 26 percent of college-aged students by 2010 , compared to developed countries that averaged 76 percent (UNESCO 20I2). This is another level of contradiction, with the continent having the fastest growing higher education sector, the highest percentage of youth seeking access to higher education, but still lagging behind in terms of enrollment ratios. UNESCO (2OI2) shows that students from sub-Saharan Africa still remain the most mobile, with the number of students studying abroad increasing from 204,900 in 2003 to 288,200 in 2012 , and mobility within Africa intensifying due to expanding domestic systems (UNESCO 20I2). On average, governments in sub-Saharan Africa invest about one fifth of their education budget in higher education, which translates into 0.9 percent of the gross domestic product.

What do the trends in higher education expansion show? First, that expansion has been able to increase enrollment rates, but not GER. The post-I990 promise of higher education expansion and quality improvement through private higher education has not materialized in the manner it was anticipated. While governments in most cases have kept their promise to provide a better regulatory environment, the expansion of private universities has been slow and cautious and, in most cases, offering curriculum in the general arts and humanities-or it has been fast and disruptive. Where this growth has been fast, like in the Democratic Republic of Congo (DRC), it has resulted into many low quality private institutions, most of which have had to be shut down. But even at current levels of access, public universities report inadequate facilities and numbers of teaching staff, and 50 percent more students per lecturer than global averages (British Council 20I4). It is this untapped potential that has engaged the fascination of global literature on higher education, with the possibilities it represents for higher education as a commercial engagement. This literature is often accompanied by the narrative on how the continent will be unable to provide enough study places for its youth; or if it will, how places provided will not meet the expectations of the students, or will be of low quality (British Council 20I4). Most of this literature argues that demographic changes and increasing demand means that the percent- 
age of international students, for example from Nigeria, is likely to overtake the percentage of students from India by 2024. It predicts that the number of Indian postgraduates, in particular, will represent only 9 percent of the growth in international student numbers to 2024around 24,000 students-compared with 29,000 postgraduates from Nigeria (University of Oxford 2015).

The second issue emerging from the trends concerns who accounts for the growth in university enrollments, and if expansion has benefited the most disadvantaged. There is a general lack of national and institutional level student data on a range of higher education indicators, and institutions do not desegregate student records by socioeconomic status. The AUC confirms the low percentage of data coverage for all priority areas, with higher education having the least reliable data (AUC 20I4); it is difficult to draw conclusions on the social composition of Africa's student body, though this would be singularly important in determining whether expansion is resulting in increased equity in a broad sense. But there are anecdotal trends that can help map out how access to higher education is distributed across the segments of society. The sketchy and fragmented data available tend to suggest that higher education expansion has widened disparities in access within and between countries, with female enrollment representing about 3 percent of the continental average of 8 percent (AUC 20IO). An analysis of Demographic and Health Survey (DHS) data from Ghana and Tanzania show that higher education participation generally remains elitist, with most students coming from the wealthier segments of society and fewer women attending (Morley et al. 2007). Hence, in terms of participation trends, the situation has not changed much compared to the diagnosis made by the World Bank in 2000. Higher education opportunities are expanding, but overall, middle-class urban high-school graduates enroll in higher education in higher numbers than graduates from poor rural areas.

It would be interesting to do an analysis of access patterns, programs of study, and labor market transition, to have a sense of how higher education is contributing to social capital formation among different sectors of society, were data available. It would also be interesting to establish the actual composition of undergraduate cohorts, between students transiting from high school to higher education institutions directly, and those joining after acquiring other qualifications and work related experience to make them eligible for enrollment. In countries such as Kenya and Uganda, where institutions have come to depend on revenues from private fee-paying students, the tendency has been to allocate more places for this last group of students and give them the flexibility to be placed in professional courses. Beyond qualifying to access higher education, socioeconomic status has come to define ease of access, the type of degree programs studied, and transition to the labor markets (British Council 20I5). A preliminary study gauging graduate employment destinations in Kenya, though based on a small sample of 472 responses, shows that 50 percent of the respondents belonged to the parallel part-time stream, with a similar percentage indicating having worked before enrolling for undergraduate degrees (Tristan, Oanda, and Oketch 20I5). These data suggest a trend where, increasingly, individual and household financing capacity determines higher education participation. Since public funding to improve the plight of poor students is declining, paying students have greater latitude to pick a course of their choice, transit or secure jobs faster, or go back to their previous jobs.

The challenge now, as it was in the I990s, remains twofold: how to raise general access and participation trends in higher education, by creating better opportunities in Africa; and how to ensure that expansion does not leave disadvantaged segments of society behind. The African Higher Education summit Declaration made in Dakar in June 2015 targets an increase of higher education enrollment ratios to 50 percent by 2063 , in line with the continent's development blueprint. However, there is no clear indication on how this planned growth will be funded, given that African countries have been unable to adequately fund major priority areas under the African Union's 2006 Plan of Action on Education (AUC 20I4). Enrollment growth compares unfavorably with population growth. UN data project Africa's population to grow by more than 50 percent by 2030 . This means that even if the current rate of education expansion is maintained for the next two decades (at 8 percent), it will not match the growth of the population (UNESCO 20I2).

In the context of this challenge, one observes mixed and contradictory trends related to public funding of higher education, and a crucial need for increased/alternative funding, to secure the gains achieved in primary and secondary education. In most countries, public funding to higher education is stagnating or declining, with about 0.78 percent of resources on average allocated to higher education as a percentage of GDP, and per student spending ranging from PPP US\$766 in Central African Republic to PPP US\$4,535 in Ethiopia in 2009 (Teferra, 2010; UNESCO, UIS 20IO). While these allocations are low compared to world average figures, they are still relatively high compared with allocations to lower levels of schooling. In I6 out of I9 countries reporting data in the region, public expenditure on a tertiary student amounts to I to Io times that of a secondary school student (UNESCO, UIS 20IO). 
Hence for higher education to "avoid the perilous path," access and expansion need to be buttressed by sound funding policy mixes that sustain gains in basic education, secure access paths for students from disadvantaged backgrounds to institutions and professional programs, expand institutions, while at the same time ensuring that higher education remains of acceptable quality and relevant.

\section{The Challenge of Governance}

Both the I9 88 and 2000 World Bank reports identified governance as a key limitation on the efficiency of universities in Africa. The concern was that there appeared to be too much government steering of the higher education sector. Political interference in leadership and management of universities infringed on institutional autonomy in a manner that compromised academic freedom. A number of policy proposals were then put forth as a remedy, including the withdrawal of direct government participation in the accreditation and regulation of universities; promotion of aacademic freedom, including the right of scholars to pursue their research and teaching without restraints from outside; shared governance between ministries of education, faculty, and university management in shaping national educational policies, with clearly defined mutual rights and responsibilities; policies to secure the financial stability of the institutions; enhanced accountability mechanisms; and close cooperation and compatibility between the different levels of steering and administration (World Bank I988; 2000).

With World Bank policies advocating investments in basic education, and African governments reducing funding to higher education, most public universities during the I99os struggled to cope with demands for expansion. There was also, during that decade, a focus on generating revenues through non-core university activities, and increasingly through the admission of fee-paying students, which in most cases went beyond the capacity of the institutions. The damage that this brought to the institutions has been documented in a number of studies (Mamdani 2007; Oanda et al. 2008). What was not envisaged in these early governance reforms was that beyond generating revenues and creating space for private higher education, governance also needed to focus on the academic mission of the institutions. If any lessons were learnt-or should have been learnt-from the turmoil in the sector from I990 to 2000 , it is that the culture of expanding higher education institutions in the absence of government support was erroneous. While the existence of political strategies for higher education (sound governance, robust funding, and commitment to quality oversight) were important, the expansion of higher education institutions needed to be guided by policies that steadied them as academic institutions.

The period 2000-20I0 saw a more formalized approach to organizing governance. By 20I3, a number of countries had several bodies in charge of higher education governance at different levels, including central government ministries; other government bodies (including councils and commissions) responsible for various functions related to higher education; and non-governmental forums or associations of higher education stakeholders, including vice-chancellors and other institutional leadership. Policies, plans, and/or strategies pertaining directly to the higher education sector were also in place (Bailey 20I4). All agencies were established in response to the need to regulate, quality assure, and coordinate growing and diversifying tertiary education sectors, a result of the need to move away from a sector where planning and operations were driven by political expediency, to one predicated on offering quality planning, and related to the skills requirements of the economy. The new bodies were also supposed to prevent political interference, especially in the establishment and licensing of new institutions, in particular private universities (Bailey 20I4).

Given the ambitions that informed the governance reforms, especially the creation of new intermediary bodies in place of direct government steering, it is important to examine if the new bodies are delivering on the promise: reducing the level of government involvement and focusing the institutions on their academic mission. Beyond running the institutions as business entities and generating funds for their operations, it is important to see how higher education governance is being conceptualized and operationalized more holistically. As Sall (20I5) argues, higher education governance in Africa must promote and establish what is recognizable as "higher education," with its academic core secured and raised to the highest level. And beyond this, Sall argues, higher education governance is a determinant factor in how institutions contribute to the solution of social contradictions and development problems - or to their aggravation. Beyond the debates on rankings, governance of higher education must be about institutions being up-to-date and innovative, and whether or not the research they do is addressing the issues that societies and policy- and change-makers are confronted with.

Looking at the landscape of higher education institutions after 2000 , it is clear, however, that the new governance frameworks have not conclusively addressed the challenges that led to their establishment, while old problems, such as quality shortage, continue to emerge in new ways. There is evidence that expansion is still politically 
driven; and while this is not wrong per se, it denies the new institutions the benefits of being founded on a better strategy. In Kenya, two universities were created in $20 \mathrm{O} 2$ and 2013 through a presidential declaration ignoring an elaborate process spelt out in the Universities Act of 20I2-that had just been adopted. The Universities Act stipulates a process of establishing new institutions, and renewing the mandate of old ones, through structured timelines. Since no planning went into the establishment of these two institutions, they have had to haphazardly create structures and academic programs to accommodate an increasing number of students. The negative outcome of this approach has however begun to show, with reports showing low skill levels among students, therefore compounding the problem of graduate employability. Studies from Uganda and Kenya show that the Universities Act, 2012 in the case of Kenya, and the universities and other tertiary institutions Act 200I, in the case of Uganda, still retain clauses that give room for political manipulation in the constitution of university governance bodies. In the wake of student strikes in South Africa, the minister of education has signalled his intention to amend the law to have more power to steer the sector's transformation process, implying that universities have failed to self-regulate for the greater public good. A similar development is taking place in Kenya, where vice-chancellors want the law amended to limit the power of professional bodies in the accreditation of programs.

So what have the new governance structures achieved, that was missing in the pre-I990 period? One would argue that it is the easiness and flexibility of establishing institutions and academic programs. That is why, when discussing post-I990 developments, the figures usually quoted are those of student enrolments, number of institutions, and their increasing capacity to generate their own operating revenues far beyond what public funding provides. This explains the quality crisis faced by higher education institutions in most of Africa, with sometimes absurd schemes to offer substandard curriculum and grades, celebrated as "innovations" to expand higher education to more deserving students.

The expansion of higher education seems to be accompanied by a decline in quality and the production of graduates who do not have the skills to power Africa's economic growth. This creates a contradiction where an increasing number of graduates exist side by side with high rates of unemployment. The African Economic Outlook (2012) documents that African graduates are confronted with high rates of unemployment because they come out of a university system that has remained rigid, still operating traditionally to serve a public sector that is fast contracting. This implies that despite the rhetoric of expanding university systems to respond to Africa's development challenges, most of the new institutions and programs are still largely duplications of the old, failed model. Statistics on levels of graduate throughput and unfilled gaps in the labor market throughout Africa reveal a crisis situation, which turns the post-I990 promise into a fraud, a kind of "ponzi scheme" that appears as a promising investment to families and individuals, only to aggravate poverty.

The extent of skills mismatch seems to be widening as enrolments soar and quality is compromised, even as labor markets struggle to fill open positions. According to the International Labour Organization (2OII), Egypt had about I.5 million unemployed graduates, while, at the same time, private sector firms were unable to fill 600,000 vacancies. South Africa had 600,000 unemployed university graduates vs. 800,000 vacancies (The Economist, 20I2). Within the East African Community, a study by the Inter-University Council (IUCEA 20I4) reveals that at least half of the graduates of East African universities lack employability skills, technical mastery, and basic work-related capabilities, and therefore are not employable. Graduates from Ugandan universities were the least qualified with $\sigma_{3}$ percent lacking employable skills; the percentage was 6I percent for Tanzania; 55 percent for Burundi; 52 percent

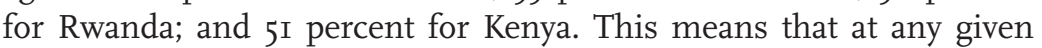
moment, half of the graduates from universities in East Africa represent a lost investment in terms of time and family resources.

Two reasons underlie the continued crisis of quality and employability. The first is that throughout Africa, higher education is not offered within a context of any holistic strategic policy; and even where such policy has been developed, like in Kenya, it is often put aside, as political pressure dictates the direction of development. The result has been increased institutions and enrollments without commensurate funding plans. More students are admitted than universities can handle, both in terms of available infrastructure and workforce. While institutions have addressed the infrastructure crisis by renting space in urban and rural areas, the workforce crisis is more difficult to solve given the time it takes to train qualified academics. Professional bodies in Kenya have had to cancel the accreditation of programs and institutions partly because of a lack of qualified academics to develop programs and offer them at the expected standards. As in Kenya, an increasing number of courses/ programs and institutions have been shut down in Uganda, DRC, and Nigeria, due to quality concerns. These institutions have been in operation and even graduated students, bringing into question the quality of governance oversight. The practice persists, because what governance 
reforms have brought about in most countries is just a restructuring of the sector by transferring much of the decision-making power to individuals and bodies that have little understanding of the academic mission of the institutions, beyond the need to generate funding.

\section{The Challenge of Knowledge Production}

How has the landscape of knowledge production changed, and to what extent have the institutions been prepared to contribute to the global pool of scientific knowledge and innovation? Higher education institutions and research centers on the continent have made strides in investing in knowledge production processes. This has been through committing internally generated resources; setting up research partnerships and establishing funding agreements with donors, and importantly, through the allocation of public resources from national councils for science and technology. At national level, the democratization and liberalization processes have put higher education institutions in a more vibrant and more transparent environment, while at the global level; the impact of the unfolding knowledge society is reshaping higher education (AfDB 2008). Despite these developments, African higher education is still at the crossroads regarding its contribution to the global production and utilization of scientific knowledge.

Many of the problems that higher education institutions find themselves in regarding knowledge production, indeed in most areas, including governance, partly emanate from the bad policy choices of the I980s. The World Bank's I988 report, while making proposals supposedly meant to "revitalize" higher education in Africa, had negative consequences, especially regarding investments in science and technology. For example, reduced public spending in higher education in favor of basic education meant that higher education institutions did not have resources to engage in science and technology research. At the same time, policies implemented under the structural adjustment package, such as reduced public budgets in education and elimination of subsidies, made importation of hardware and software required for scientific research more expensive for African institutions. On the other hand, as the World Bank was advising African countries to adopt these policies, it reduced its own funding to higher education. From I9 85 to I989, only I7 percent of the Bank's worldwide education spending went towards higher education, and this declined to 7 percent from 1995 to I999 (Bloom, Canning, and Chan 2006). The collapse of knowledge production systems that these two decades of neglect occasioned in African higher education institutions (including triggering brain drain) has been discussed in a number of studies. It is important therefore to have continued reflections on whether the same World Bank and associated donors that were the cause of the crisis can turn out to be the source of the solution.

At continental and institutional levels, a number of initiatives, some still underway, have been taken to reverse this situation. The goal is to have the continent's universities and research centers build strong foundations for knowledge production, especially in the areas of science and innovation. The African Union has been especially engaged in designing robust funding and research policies. In 2005, the African Science and Technology Consolidated Plan of Action was launched by the AUC and the secretariat of the New Partnership for Africa's Development (NEPAD) (AUC 2005). The plan was subsequently adopted in January 2007 at the African Union heads of states meeting in Addis Ababa, Ethiopia. Part of the agreement was to have African countries allocate at least I percent of their gross domestic product to research and development by 2020 , revitalize African universities, establish a pan-African intellectual property organization to help protect indigenous innovations, and start on a 20 -year strategy to promote cooperation among states on research in biotechnology (AUC 2007).

Revitalizing higher education and strengthening science and technology also feature in "Agenda 2063 ," the continent's recent development blueprint. The blueprint envisages that by 2063 , at least 70 percent of all high school graduates will go on to tertiary education, with 70 percent of them graduating in the sciences, technology, and innovation programs, thus laying the basis for competitive economies built upon human capital to complement the continent's rich endowments in natural resources (AUC 20I4). Agenda 2063 also envisages a harmonized higher education system, with the Pan African University and several centers of excellence across the continent; a Pan African Virtual university that would utilize technology to provide mass, post-school education; a university sector playing an instrumental role in these processes; a majority of Africans educated and skilled in science, technology, research and innovation, as well as in vocational occupations; and capacity for the trained to remain and work within the continent by creating conditions that stem brain drain (AUC 20I4).

The African Development Bank has also come up with initiatives to help revitalize higher education and develop science and technology capacities in particular. The Bank's Strategy for Higher Education, Science and Technology in Africa (2008), focuses on investing in reforming and transforming higher education systems in Africa. This, the strategy proposes, would be through strengthening national and regional centers of excellence in the areas of agriculture and livestock, 
health sciences and health delivery support services, engineering, business enterprise, training of teachers and educational managers, and energy; building and/or rehabilitating the existing science and technology infrastructure, including tertiary education institutions; and linking higher education, science, and technology (HEST) to the productive sector. Under this strategy, the Bank is funding a number of higher education projects in various African countries, aimed at improving and expanding access to universities, building capacity in public higher education institutions through postgraduate training of faculty staff in the newly established public universities, training staff in institutional management, governance, public-private partnerships development models, and maintenance and sustainability; strengthening applied research and innovation in Science, Technology and Innovation (STI), and supporting the establishment/strengthening of the production and entrepreneurship incubation centers at universities to enhance practical training (Kunene/AfDB 20I3).

The third initiative has been strengthening science councils, most of which were established in the I970s in a number of African countries. The focus here is to have specialized units to mobilize funding for research, besides funding research and innovation at universities and research centers. In addition, the councils engage with the dissemination of research findings and support scientific publishing and the collection of R\&D data and statistics (Mouton, Gaillard, and Van Lill 20I4). However, given the low rate of R\&D investment in most countries, the councils face the challenge of inadequate and unsustainable public funding and are unable to meet the high demand from the research community (Mouton, Gaillard, and Van Lill 20I4). A strategy to support the councils has been developed through a project funded by the United Kingdom's Department for International Development (DfID), Canada's International Development Research Centre (IDRC), and South Africa's National Research Foundation (NRF) (Sawaheid 20I5). The overall aim of the strategy is to strengthen the capacities of the science councils in order to support research and evidence-based policies that will contribute to economic and social development, increase public investments in strengthening the capacities of the councils, and help change the quality, quantity, and impact trajectory of Africa's STI products and services (Sawaheid 20I5). But a strategy exclusively dependent on donors to fund and strengthen the councils might still have inherent flaws that can undermine the quality and relevance of scientific innovations for Africa.

Despite all these initiatives, the STI gap does not appear to be closing, nor is the contribution of African institutions to global knowledge pro- duction increasing. The UNESCO Science Report (20I5) frames the problems African institutions face in this perspective. While asserting that in the long run, no region or nation can remain a simple "user," but must also be "creator" of new knowledge, the report points out that closing the innovation gap is a necessary role of universities in terms of teaching and research missions. However, the report points out that many countries in Africa today produce fewer inventions than they did in the early I990s (UNESCO 2015).

Arguably, some countries have raised their gross domestic expenditure on R\&D (GERD): for instance Ethiopia has raised its GERD from 0.24 percent (2009) to 0.6 I percent (2013) of the GDP; Uganda has raised its GERD to 0.48 percent (20I0), from 0.33 percent in 2008 ; but still this falls short of the target of I percent agreed according to the science Plan of Action (AUC 20I4). Over the last decade, a number of African countries and institutions have developed encouraging blueprints and strategies to guide investments and knowledge production in science and technology. But the focus on these strategies is often temporary. In Kenya for instance, the Science, Technology and Innovation Act passed in 2013 contributes to the realization of the "Kenya Vision 2030," which promises to move Kenya to a middle-income country with a skilled workforce by 2030 . According to the Act, Kenya commits to increasing spending on R\&D to 2 percent of the GDP, from 0.79 percent (Republic of Kenya, 20IO). But in spite of this plan, expenditure on $R \& D$ has decreased from 0.7 percent to 0.5 percent in 2015 . The same trend has been documented in West African countries, where, despite the commitment from ECOWAS through its "Policy on Science and Technology" (20II), the research sector has had little impact, due to a lack of national research and innovation strategies, low investment in R\&D, limited private sector involvement, and limited intraregional collaboration among researchers (UNESCO 20I5). Timely and comprehensive data would reveal the real extent of the gravity of the situation. The AUC (20I4), points out the difficulty to assess progress in promoting research and knowledge production by African universities and research centers as a result of the lack of quality data on the productivity of faculty members. Besides, most African universities remain largely teaching institutions rather than research institutions, which limit research capabilities (AUC 20I4).

In the absence of robust internal funding policies, research and knowledge production, if any, still continues to depend, and be influenced by, external donors. Beyond the blueprints, no substantial budgets are spent on research, even by the institutions. Even when funding is available, there seems to be a lack of ideological grounding 
on the direction of science and technology, to support the continent in terms of prioritization of research and engagement with the communities, and ensure a positive synergy between the knowledge produced and its implications on welfare. One policy document that does not seem to have much traction on R\&D policies and institutional strategic plans is the "African Manifesto for Science and Technology" (20I0). The document was developed to promote self-rule in STI in Africa, by restoring the confidence of Africans in African STI and African experts, focusing public and private investments in building sustainable STI infrastructures, and giving guidance in the adoption of proactive policies to fully embed African STI in African societies (ATPS 20I0:6). The manifesto is framed in the context of the wider political economy in which science and knowledge production are practiced. It addresses issues on the production and utilization of global scientific knowledge, and seeks strategies to allow Africa play an important role in producing knowledge relevant to its development-in the context of a global divide in which STI agenda setting and prioritization remain the prerogatives of the global North. Interestingly, sections of the 2015 UNESCO science report echo these preoccupations, emphasizing the need for R\&D to encompass indigenous knowledge and languages. However, neither the AUC nor institutional level R\&D strategies make any reference to the ideological logic of the manifesto.

Given the foregoing scenarios, it is difficult to draw conclusions on what path knowledge production processes in African higher education are stewarding the development process. $R \& D$ and other science and technology initiatives and trends are dependent on funding sources, and public funding has hardly been increased to secure public interest in R\&D processes. A good example of this trend is in Kenya, where private funding has been used to undertake research that has justified the adoption of genetically modified maize varieties, with the government keen to push this through. The only opposition to this has largely come from local farmers in Kenya, while the research community, especially at the universities, remained mute. This is akin to what happened in the I980s, when academics either remained silent, or were hired as consultants to justify the adoption of Structural Adjustment Programs (SAPS) and the redirection of funding away from higher education institutions. Science councils have been strengthened, but with no adequate funding to undertake their missions. With the World Bank's change of perspective, there seems to be more interest in donors getting engaged in African higher education, especially through scientific collaboration and support for research capacities in the institutions. Caution is necessary here to ensure such engagements do not distort indigenous research agendas, or further erode research capacity in the universities through giving support to non-university entities and individual research undertakings. There seems to be a silent design to move research and innovation away from universities, especially in donor-funded programs, by creating and strengthening auxiliary bodies whose mandate undercuts that of the universities.

\section{The Challenges of Relevance}

The debate on the relevance of higher education institutions in Africa has largely been framed at two levels. At one level, given the colonial origins of their structures and missions, questions have been raised about their authenticity and about the logic that underpins their knowledge production processes. At the second level, there is a concern about programs and enrolment concentrations in the social sciences and humanities (SSH), in an environment that requires more skills in physics and engineering. The problem with this second debate is the manner it is framed, implying distinct knowledge categorizations that can exist independently from each other. Taken together, these concerns have resulted in a critique of the dominant Eurocentric academic model as continuing to manifest "epistemic coloniality" in African higher education institutions. The endless production of theories that are based on European traditions are produced nearly always by European scholars who are the only ones accepted as capable of reaching universality; a particular anthropological knowledge, which is a process of knowing about Others-but a process that never fully acknowledges these Others as thinking and knowledge-producing subjects (Ibarra Colado 2006).

When raising the question of enrolment concentrations in the SSH, one tends to look primarily at numbers, not at the content of these disciplines and at what they are meant to achieve. Relevance is seen in terms of appropriateness of the skills gained in relation to employability, a narrow view of the human capital approach. This leads to the current frustration that higher education in Africa is producing unemployable graduates-without considering the impact of the global economic downturn, beyond the control of individual African countries. It should be remembered that part of the reform policies in the I980s and I990s entailed government privatization of state enterprises that in the past employed a large number of graduates from the universities. Once the enterprises were privatized, sometimes to multinationals, and sometimes with advocacy for flexible labour regulations, the share of national graduates employed into these organizations declined, while enrolments and outputs from the universities increased. This was therefore 
not just a failure of the higher education institutions. The tragedy is that such lamentations tend to lead to continuous changes in the structure of higher education systems, resulting in more distortions.

Beyond the challenge of employability, there is a recurrent question about the colonial logic of the institutions and the curriculum, and the need of reforms to make them more "African" in orientation through deliberate policy strategies and to repackage them in order to address the various dimensions of the continent's development challenge. This has been captured in the literature as the quest for the decolonization and Africanization of African higher education. Such concerns have been raised since the postwar period. With the establishment of universities modeled along European standards-but with a specific mandate with regard to the type of education and worldview to develop in the African mind-decolonization for Africans meant being allowed to get more university education. In the period immediately following independence, much effort was invested to admit a larger number of Africans to the institutions, and send others abroad for higher education, as part of the modernity project.

The following phase of nationalization of universities and of systematically hiring Africans as administrators and academics was then seen as sufficient Africanization, and by implication, decolonization. There was not much concern about the nature of the curriculum, especially in the SSH. The few scholars who tried to question the colonial logic, as happened during the "Dar es Salaam" debates or Ngugi Wa Thiong'o's questioning of colonial languages and the place of African languages and literature ${ }^{2}$, were met with repression from the state and labeled as unpatriotic and bending to the whims of the very colonial logic that they were resisting.

At the beginning of the I980s, with the apparent failure of the western development model, social science assumptions that underpinned such development model began to the questioned. This was helped, in large measure, by the coming of age of "postcolonial studies" and their critical appraisal of western knowledge production and dissemination, together with a search for alternative ways of researching and representing the reality of colonized societies. The articulation of endogeny as the basis for the development of science and knowledge relevant to

2. The Dar es Salaam debates refers to scholarly engagements at the University of Dar es Salaam in the early 19705 Class, State and Imperialism' The debates, among others, aimed at the raising the con sciousness of the working on how capitalist relations of production and the emerging class of African leaders constituted an oppressive force that needed to be overthrown a fact that attracted repression of the academics by the state. Nugi's articulation of the same issues based on the need to decolonize African education systems through language attracted the same wrath from the state.
Africa began to gain acceptance, especially in the teaching of SSH in African universities (Ake I986). More recently, the issue of the decolonization of universities has emerged more strongly in South Africa, in the context of the language of transformation, and more specifically to question the rate at which black South Africans access the institutions as students, faculty, and staff, and the extent to which research and teaching in the SSH are representative of the black experience. The issues in South Africa, like elsewhere on the continent, revolve around how Africa is to be taught in post-apartheid universities, the direction of curriculum transformation, and the appointment of African and black faculty (Mamdani I998). This struggle has largely informed the drafting of the South African Charter for Humanities and Social Sciences. The debate about who can speak legitimately about Africa continues, and extends to more general questions in the social sciences about who can (and should) study what, who can speak on whose behalf, and the value of anthropological methods such as embedded research (Smith 2008).

The urge to decolonize the institutions, especially through a "repackaging" of SSH, has often gone hand in hand with donors policies giving new directions to institutional development. For example, the World Bank's change of perspective on higher education in Africa has been accompanied by policy recommendations to promote employability. SSH have been declared irrelevant to the needs of Africa's development: according to the World Bank and other donors, large enrolments in SSH are among the deficits in the system that needs to be corrected. Hence, SSH are underfunded and there is a dearth of efforts in most countries to discuss their role Africa's development and the reconstruction of the continent's future.

The World Bank and other donors' stand against SSH is in contradiction with the current engagement of a number of donors and western foundations in programs to support $\mathrm{SSH}$ programs in a number of African universities, including interventions aimed at curriculum reform and postgraduate education. What is most scaring about this approach is a creeping sense that how SSH should be taught, and how research in these disciplines has to be undertaken, is going to be designed elsewhere. It is important to observe that the same actors that seem to show support for the teaching of SSH are almost the same ones that think over-enrollment in SSH in African universities is one of the major shortcomings of the system. This kind of approach on designing a specific SSH program in African universities was applied in the I970s, in what has come to be referred to as the "internationalization of the social sciences" or the "Americanization of the social sciences." 
Then as now, American foundations led this process—-with Rockefeller and Ford supporting the establishment of "Institutes for Development Studies" at a number of African universities in the I970s and early I980s. These institutes now lack the infrastructure and research funds they had then to influence social policy discourse in African countries. Back then, there were centers of critical thought at a number of African universities that provided a different ideological bent to teaching and research in SSH. For example, in East Africa, in the context of what came to be referred to as the "Dar es Salaam debates," social scientists and academics at the University of Dar es Salaam contributed to substantive theoretical issues regarding, for instance, the nature of farmers' agrarian commodity production and the world market, and gender relations within farmer household units of production. The strength of Dar was that it nurtured a generation of social scientists and intellectuals who contributed to understanding and interpreting the specific problems of development in Africa.

At the same time that SSH are being marginalized in African higher education, their contribution to human development and security is acknowledged elsewhere. In the United States, a report by the Commission on the Humanities and Social Sciences, "The Heart of the Matter" (20I3), argues for more investments in SSH disciplines, pointing out that humanities are essential to efforts to achieve important national goals: educating Americans in the knowledge and skills they need to thrive; fostering an innovative and competitive society; and equipping the nation for leadership in an interconnected world. Likewise, the League of European Research Universities (LERU) advise that, within in the "Horizon 2020" European Union program, SSH remain essential fields for European research, as they generate new and intrinsically valuable knowledge pertaining to all human aspects of the world, of vital importance to the future of Europe. This includes knowledge addressing societal challenges such as international conflicts, human rights, ethics, religious traditions of acute contemporary relevance, economic and educational inclusion, institutions and governance networks, social and environmental resilience, changing media, literacy, identities and cultural memories, linguistic diversity, creative industries, cultural heritage, lifelong education and learning, developmental disorders, and man-machine interactions, among others (LERU 2013.3). A recent attempt to downsize SSH in Japan was also met with immediate resistance from liberals who saw this as an attack on Japanese democracy, pointing out how these disciplines foster critical thinking and prepare students to engage in an increasingly globalized workplace and demonstrate cross-cultural communication, marketing, and design skills
(Kingstone 20I5). It is therefore in Africa that SSH are portrayed as an inconvenience for higher education systems, which should rather focus on STEM disciplines. With such an emphasis, the future of SSH and all they contribute to in the production of relevant knowledge is vulnerable. In most institutions, with the neglect in funding of the last two decades, investments in SSH has declined or been removed altogether from the institutions' budgets. Staff development programs and student enrollment in some of SSH programs have declined substantially.

On the brighter side, SSH are not entirely marginalized. The AUC'S "Agenda 2063, The Africa We Want» (AUC 20I4), for example, focuses on achieving «an integrated, prosperous and peaceful Africa, driven by its own citizens and representing a dynamic force in the global arena", which can only be achieved through a balance between STEM and SSH at African universities.

The need to revitalize research and teaching of SSH in African universities is urgent. What is needed is a program that is borne out of internal reflections on the nature of approaches that are needed. Because of the funding crisis, there is a real danger that institutions and academics may rush to embrace any external support, even where this will undermine the revitalization of SSH germane to the development needs of African society. It is important that institutions and academics in Africa have a robust debate about this.

\section{Conclusions}

Higher education in Africa has made strides since the crippling effects of SAPS in the I980s and early I990s. Institutions have expanded both in numbers and student enrollments. However, in most cases, the quality of academic programs in most of institutions has come under question. Under new and changed governance structures, most have diversified their funding sources, though adequate funding still remains a challenge. At both continental and national levels, a number of policy initiatives have been undertaken to revitalize the sector and strengthen its critical role in the continent's development. But questions still remain on the impact of the sector, given that the internal logic governing its operations is a continuation of the colonial foundations upon which much of the university sector in Africa was built. The current marginalization of SSH, disciplines that should add a value orientation to the work of the institutions, and the growing influence of external forces in all teaching and research in $\mathrm{SSH}$, raise questions on the path institutions must take to strive for African authenticity. 


\section{References}

Africa Economic Outlook (2015). Regional Development and Spatial Inclusion. African Development Bank/Organization for Economic Co-operation and Development/United Nations Development Program.

African Development Bank (2008). Strategy for Higher Education, Science and Technology. AfDB. Operations Policies and Compliance Department (ORPC) Human Development Department (OSHD).

African Union Commission (2OI4). AU Outlook on Education Continental Report. AUC/Association for the Development of Education in Africa (ADEA)/ Africa Development Bank (AfDB). Tunis, Tunisia.

African Union Commission (20I4). Agenda 2063; The Africa We Want. Africa Union Commission, Addis Ababa, Ethiopia.

African Union Commission (2007). Harmonization of Higher Education Programs in Africa: A Strategy for the African Union. COMEDAF III's Work Document No AU/EXP/EDUC/2 (III), Part II. Addis Ababa: African Union (AU).

African Union Commission (2005). Africa's Science and Technology Consolidated Plan of Action. Addis Ababa.

African Union Department of Human Resources, Science and Technology (20II). Report of the Midterm Evaluation of the Second Decade of Education for Africa, 2006-2015 Incorporating comments arising out of the AU stakeholder Validation Meeting. Mauritius, 23rd -25 th November 20II.

American Academy of Arts and Science (2013). The Heart of the Matter: The Humanities and Social Sciences for a vibrant, competitive, and secure nation. American Academy of Arts and Sciences . Cambridge, Massachusetts.

Aina, T. (20I5). Reclaiming Excellence, Rebuilding Communities, and Transforming Systems: Critical Imperatives for African Higher Education Today. Keynote Address to the CODESRIA African Diaspora Support to African Universities Research Partnerships Networks Methodological Work shop. Nairobi, Kenya, I4th-I6th November.

Ake, C,.(I982). Social Science as Imperialism: The Theory of Political Development, Ibadan: Ibadan University Press.

Bailey, T. (20I4). The Roles and Functions of Higher Education Councils and Commissions in Africa; A Synthesis of Eight Case Study Report. Centre for Higher Education Transformation (CHET).

Bloom, E, Canning, David, Chan, Kevin and Luca, D. Lee (20I4) Higher Education and Economic Growth in Africa. International Journal of African Higher Education, I(I): 23-57.
British Council (2015). Io Expansion of university education and the challenges of quality and graduate employability: Kenya; www. britishcouncil.org/ihe

British Council. (20I4). Can higher education solve Africa's job crisis? Understanding graduate employability in Sub-Saharan Africa. www. britishcouncil.org/education/ihe

Brock-Utne, B. (2003). Formulating Higher Education Policies in Africa: The Pressure from External Forces and the Neoliberal Agenda Journal of Higher Education in Africa. vol.I n ${ }^{\circ}$ I, CODESRIA, Dakar.

Federici, Silvia, George Caffentzis, and Ousseina Alidou, eds. (2000). A Thousand Flowers: Social Struggles against Structural Adjustment in African Universities. Trenton, NJ : Africa World Press.

Ibarra Colado, Eduardo (2006). Organization Studies and Epistemic Coloniality in Latin America: Thinking Otherness from the Margins, Organization, Vol. I3, No. 4, 463-488.

Inter-University Council for East Africa/East Africa Business Council. (20I4). Regional higher education qualifications gaps; Composite Study; Vol ii. East African Community Qualifications Framework for Higher Education situation Report.

Kunene, B./AfDB (20I3). AfDB's initiatives in Higher Education. A Presentation to the Regional Initiative in Science and Education (RISE). 25-26 October, Johannesburg, South Africa.

League of European Research Universities, LERU. (2013). The Future of the Social Sciences and Humanities in Europe: Collected LERU Papers on the SSH Research agenda. Advice paper No I3.

Mahmood M. (2007). Scholars in the Marketplace. The Dilemmas of Neo-Liberal Reform at Makerere University, 1989-2005. Dakar, CODESRIA.

Mamdani, M. (1998). Is African studies to be turned into a new home for Bantu Education at UCT? Social Dynamics, 24(2), pp. 63-75.

Morley, L. et al. (2007). Widening Participation in Higher Education in Ghana and Tanzania: Developing an Equity Scorecard. Working Paper 1: Setting the Scene. An ESRC/DfID Poverty Reduction Program funded Research Project.

Mouton, J.; Gaillard,J. and van Lill , M. (20I4). Science Granting Councils in Africa. Final Technical Report for International Development Research Centre (IDRC-CRDI). Stellenbosch University ; Centre for Research on Evaluation, Science and Technology and IRD.

Oanda, I.O.; Chege, F.; and Wesonga, D. (2008). The implications of privatization and private Higher Education on Access and Knowledge production in Kenya; CODESRIA Book Series, Dakar, Senegal.

Robertson, S.L. (20II) The Strange Non-Death of Neoliberal Privati- 
zation in the World Bank's Education Strategy 2020, Centre for Globalization, Education and Societies, UK; University of Bristol.

Samoff, J. and Bidemi, C. (2004 ). Conditions, Coalitions, and Influence: The World Bank and Higher Education in Africa. Prepared for presentation at the Annual Conference of the Comparative and International Education Society Salt Lake City, 8-I2.

Sawaheid, W. (20I5). Initiative to Strengthen I6 African Science Councils. University World News; 25 September. Issue No 383.

Smith, K. (2008). Has Africa got anything to say? African contributions to the theoretical development of International Relations: a preliminary investigation. Paper presented at the BISA Africa and IS workshop, 9 July.

The African Technology Policy Studies Network, ATPS (20I0). The African Manifesto for Science, Technology and Innovation. Nairobi, The African Technology Policy Studies Network (ATPS).

Tristan, M., Oanda I., and Oketch, M. (20I5). Gauging graduate employment destinations in Sub-Saharan Africa. Preliminary findings from an-on-going Study in Kenya.

University of Oxford. (20I5). International Trends in Higher Education. Oxford.

UNESCO (20I5). UNESCO Science Report; Towards 2030. UNESCO. UNESCO Publishing.

UNESCO (20I2). Tertiary Enrolments, 1999-2012 By Region. UNESCO Institute for Statistics http://www.uis.unesco.org/Pages/default. aspx

UNESCO, Institute of Statistics. (2010). Trends In Tertiary Education: Sub-Saharan Africa. UNESCO, UIS.

World Bank/African Development Bank (20II). The Africa Competitiveness Report. World Economic Forum; the World Bank and the African Development Bank

World Bank (2010). Financing higher education in Africa. Washington, DC: World Bank.

World Bank (2002).Constructing Knowledge Societies; New Challenges for Tertiary Education, Washington DC, The World Bank.

World Bank and UNESCO (2000). Higher Education in Developing Countries: Peril and Promise. Washington DC-Paris: World BankUNESCO.

World Bank (2000). Can Africa Claim the 21stCentury? Washington D.C, The World Bank.

World Bank (I988). Education in Sub-Saharan Africa: Strategies for Adjustment, Revitalization, and Expansion; Washington: World Bank. 